\title{
Application of Different Combination of Nitrogen, Phosphorus with Naphthalene Acetic Acid in Late Sown Wheat to Improve its Grain Yield
}

\author{
Muhammad Afnan Rabbi, Iqtidar Hussain*, Ejaz Ahmed, Muhammad Saad and Aitezaz Ali Asad Shahani
}

Department of Agronomy, Faculty of Agriculture, Gomal University, Dera Ismail Khan, Khyber Pakhtunkhwa, Pakistan.

\begin{abstract}
Delay in harvesting kharif crops such as cotton, rice and sugarcane, compel the growers to sowing late wheat and due to this wheat production becomes low. A foremost challenge for crop production is to increase its economic yields in an endurable manner by improving fertility of the soil. Many struggles have been done to enhance the wheat productivity since last decade. Use of synthetic plant growth regulators with nitrogen supply seems to be fruitful in this regard. So, an experiment was designed to assess the effect of various doses of $\mathrm{N}$ and $\mathrm{P}_{2} \mathrm{O}_{5}$ with combination of exogenous application of naphthalene acetic acid levels in late sown wheat in agro climatic conditions of Dera Ismail Khan, KP., Pakistan. Data registered on agronomic parameters i.e. plant height $(\mathrm{cm})$, spike weight $(\mathrm{g})$, spike length $(\mathrm{cm})$, number of tillers, weight of 1000 grains (g), number of grains spike ${ }^{-1}$, biological yield $\left(\mathrm{kg} \mathrm{ha}^{-1}\right)$, yield of grain $\left(\mathrm{kg} \mathrm{ha}^{-1}\right)$, yield of straw $\left(\mathrm{kg} \mathrm{ha}^{-1}\right)$, productivity score and harvest index were significant in different doses of $\mathrm{N}$ and $\mathrm{P}_{2} \mathrm{O}_{5}$ with different levels of NAA. Maximum grain yield and yield contributing parameters were acquired from fertilizer dose of $180 \mathrm{~N}$ and $120 \mathrm{P}_{2} \mathrm{O}_{5}$ and PGR level (50 $\left.\mathrm{ml} \mathrm{NAA} \mathrm{ha}^{-1}\right)$. Based on one year study, $50 \mathrm{ml} \mathrm{ha}^{-1}$ of NAA with optimum dose of $\mathrm{N}$ and $\mathrm{P}_{2} \mathrm{O}_{5}$ seemed to gain a maximum net return from wheat crop in agro-ecological condition of Dera Ismail Khan.

Received | October 03, 2020; Accepted | May 03, 2021; Published | June 18, 2021

*Correspondence | Iqtidar Hussain, Department of Agronomy, Faculty of Agriculture, Gomal University, Dera Ismail Khan, Khyber Pakhtunkhwa, Pakistan; Email: iqtidarhussain453@yahoo.com

Citation | Rabbi, M.A., I. Hussain, E. Ahmed, M. Saad and A.A.A. Shahani. 2021. Application of different combination of nitrogen, phosphorus with naphthalene acetic acid in late sown wheat to improve its grain yield. Pakistan Journal of Agricultural Research, 34(3): 454-461.

DOI | https://dx.doi.org/10.17582/journal.pjar/2021/34.3.454.461

Keywords | Nitrogen, Phosphorus, Naphthalene acetic acid, Wheat, Grain yield
\end{abstract}

\section{Introduction}

W Theat (Triticum aestivum L.) is not only a major crop for more than $1 / 3^{\text {rd }}$ of the world's population, but it is also the amplest source of energy and nutrition for humans. Therefore, it is important to come up with favorable conditions for wheat crop growth to achieve high qualitative and quantitative yields (Gerami et al., 2013). Delaying in kharif crops harvesting such as cotton, rice and sugarcane, compel the growers to sowing late wheat and ultimately their production becomes low. To maintaining the soil fertility and meet our food safety objectives, increasing fertilizer intake is one of the most fundamental factors influencing the management of soil fertility and agricultural production. These conditions exist in many of the regions in the country, which seriously affects crop production due to which wheat yield becomes stagnant since few years. Breaking stagnancy and further improvement in grain yield is a problem specially in late sown wheat. The application of fertilizer in Pakistan is mainly in favor of $\mathrm{N}$ alone, which further emphasizes nutritional deficiencies, in particular phosphorus and 
resultting in low productivity (Khan et al., 2008). The use of phosphorus may encourage prevalence of malnutrition in developing countries. Fertilization with phosphorus $(\mathrm{P})$ and nitrogen $(\mathrm{N})$ fertilizers has maximized cereal crop yields to meet growing food requirements (Murphy et al., 2008). Well-adjusted fertilizer application is the key components of modern production technologies that refer to the supply of nutrients to plants, not only in adequate quantities but also in balanced amounts. Appropriate and balanced fertilizer reduces the prospects of environmental contamination (Khan et al., 2008). Application of growth regulatory hormones is a recent technique in this direction. Plant hormones in a broad sense are organic compounds which play key role in growth, development and production of crops, avoiding fruit/ flower drop for a longer period (Aslam et al., 2010). Hormones influence physiological processes and synthetic growth regulators can improve the growth and development of field crops. Naphthalene acetic acid (NAA) has been used to boost growth and cereal yields (Raoofi et al., 2014). NAA is known to be artificial growth promoter used at proper concentration, influences growth and development of cereal crops and other physiological and biochemical processes (Islam and Jahan, 2016). The use of NAA combine with nitrogen and phosphorus can show a significant role in minimizing the cost of crop production and in balancing nutrient use to obtain better environmental and commercial results (Islam and Jahan, 2016). The objective of this work was to evaluate the efficiency of nitrogen and phosphorus to increase wheat productivity in combination with foliar application of NAA in late-sown wheat.

\section{Materials and Methods}

The research trial on integrated use of nitrogenous and phosphatic fertilizers along with naphthalene acetic acid was investigated on late sown wheat to improve its economic yield capacity. The experiment was carried out at Research farm of Agriculture Faculty, Gomal University, Dera Ismail Khan, KP, Pakistan.

The experiment was based on split type arrangements with Randomized Complete Block Design (RCBD). Properly prepared and well manipulated seed bed was adopted on moist (wattar) condition soil by one deep ploughing accompanied by 1 to 2 planking. The seed rate was $140 \mathrm{~kg} \mathrm{ha}^{-1}$ and variety was Hashim- 08 . The net size of the plot was $3 \mathrm{~m} \times 1.8 \mathrm{~m}$ and each plot was comprising 6 rows with $30 \mathrm{~cm}$ distance. Every treatment was repeated three times. The four levels of $\mathrm{N}$ and $\mathrm{P}_{2} \mathrm{O}_{5}$ fertilizers @ (0:0, 60:40, 120:80 and 180:120 NP kg ha-1) were applied to T1, T2, T3, T4 at sowing time ( $\mathrm{N}$ was used in 2 splits) plots while potassium was added as recommended as $60 \mathrm{~kg} \mathrm{ha}^{-1}$ all plots. NAA was applied at 0,50 and $100 \mathrm{ml} \mathrm{ha}^{-1}$ to GR1, GR2 and GR3 at booting stage. All other cultural practices were pursued in accordance with the location standard guidelines.

\section{Parameters studied}

During experimentation the pursuing parameters were studied from the collected data.

\section{Plant height $(\mathrm{cm})$}

Ten random plants were selected at physiological stage and measured their height from each experimental unit.

\section{Number of tillers}

Data concerning the number of tillers were obtained from every experimental unit at the time of harvest by counting the tillers in a random area of $1 \mathrm{~m}^{2}$.

\section{Spike weight (g)}

Ten spikes were cut off from each sub plot randomly and measure its weight.

\section{Spike length (cm)}

Ten spikes from each subplot were fetched randomly and measured for the spike length.

\section{No. of grains spike ${ }^{-1}$}

In each subplot ten spikes were taken randomly, after threshing and cleaning grains was counted.

\section{Thousand grains weight (g)}

The weight of 1000 grains was reckoned from one seed lot of every sub-plot.

\section{Biological yield $\left(\mathrm{kg} \mathrm{ha}^{-1}\right)$}

In each sub plot an area of $1 \mathrm{~m}^{2}$ was harvested and its weight determined and converted to $\mathrm{kg} \mathrm{ha}^{-1}$ by the formula.

\section{Biological yield $\left(\mathrm{kg} \mathrm{ha}^{-1}\right)=$ Biomass $\left(\mathrm{kg} \mathrm{m}^{-2}\right) \times 10000$}

\section{Grain yield ( $\left.k g h a^{-1}\right)$}

One $\mathrm{m}^{2}$ was harvested and threshed manually from every treatment. After threshing, grains were dried 
for 48 to $72 \mathrm{hrs}$ on open environment to decrease moisture content and was measured their weight and converted into $\mathrm{kg} \mathrm{ha}^{-1}$ as under.

$$
\text { Grain yield }\left(\mathrm{kg} \mathrm{ha}^{-1}\right)=\text { Yield }\left(\mathrm{kg} \mathrm{m}^{-2}\right) \times 10000
$$

\section{Straw yield}

Straw yield was computed by using the following method.

\section{Straw yield $=$ Total biomass - Economic yield}

\section{Harvest index (\%)}

It was evaluated by using the formula:

\section{$H I=$ Economic yield $/$ Biological yield $\times 100$}

\section{Productivity score}

The sum of grain yield, biological yield and harvest index is referred to as productivity score (Stoskopf, 1981).

\section{$P S=G Y+B Y+H I$}

\section{Results and Discussion}

\section{Plant height $(\mathrm{cm})$}

Data concerning plant height in Table 1 was significantly impacted by the application and interactions in wheat of different levels of nitrogen, phosphorus, and naphthalene acetic acid. Mean values for levels of NP revealed that $T_{4}$ (180:120) had the highest plant height $(89.42 \mathrm{~cm})$ compared to other fertilizer levels while from $\mathrm{T}_{4} \mathrm{xGR}$ registered maximum plant height $(94.13 \mathrm{~cm})$ in interaction. $\mathrm{GR}_{2}\left(50 \mathrm{ml} \mathrm{NAA} \mathrm{ha}^{-1}\right)$ produced taller plants $(86.56$ $\mathrm{cm})$ than $\mathrm{GR}_{1}$ and $\mathrm{GR}_{3}$. While $\mathrm{T}_{2}(80.51 \mathrm{~cm})$ and $\mathrm{T}_{3}$ $(82.79 \mathrm{~cm})$ seems to be non significant to one another. The minimum plant height was logged from control treatment $\mathrm{T}_{1}(72.19 \mathrm{~cm})$ and $\mathrm{GR}_{1}(75.70 \mathrm{~cm})$ while in interaction $\mathrm{T}_{1} \mathrm{xGR}$ expressed the lowest plant height $(67.20 \mathrm{~cm})$. This was due to dense in $\left(\mathrm{T}_{4} \mathrm{xGR} \mathrm{R}_{2}\right)$ population which cause a competition among the plants for light and better survival. Bakhsh et al. (2011) described that foliar applied NAA improved tillers as opposed to control while Khan et al. (2014) recorded taller plants where maximum amount of NP fertilizers were applied.

\section{Number of tillers at maturity}

Table 2 data analysis revealed that the effect on late sown wheat of different levels of $\mathrm{N}$ and $\mathrm{P}$ with naphthalene acetic acid and their interactions indicated significant effects on the number of mature tillers. Mean value of number of tillers showed that fertilizers doses $T_{4}(180: 120)$ had maximum number of tillers at maturity (215.22) followed by $\mathrm{T}_{3}$ (184.67) while $\mathrm{GR}_{2}\left(50 \mathrm{ml} \mathrm{ha}^{-1}\right)$ NAA recorded maximum number of tillers (186.92) followed by $\mathrm{GR}_{3}$ (179.67) by foliar application of NAA. In interaction of these two factors $\mathrm{T}_{4}\left(180: 120 \mathrm{~kg} \mathrm{ha}^{-1}\right) \times \mathrm{GR}_{2}\left(50 \mathrm{ml} \mathrm{ha}^{-}\right.$ $\left.{ }^{1}\right)$ registered high number of tillers. Minimum tillers recorded from control treatment $\mathrm{T}_{1}(150.11)$ and $\mathrm{GR}_{1}$ (170.83) and (141.00) in interaction from $\mathrm{T}_{1} \times \mathrm{GR}_{1}$. This may be due to availability of optimum amount of nutrients at tillering stage and NAA may produce more meristematic centers at the base of plant for tillering. Islam and Jahan (2016) reported similar type of results and proclaimed that foliar application of NAA enhanced nitrogen and phosphorus uptake which gave the result of high tillering.

Table 1: Effect of N: $P$ and NAA application on plant height $(\mathrm{cm})$ of wheat.

\begin{tabular}{lllll}
$\begin{array}{l}\text { NP Levels } \\
\text { (kg/ha) }\end{array}$ & \multicolumn{2}{l}{ NAA Levels (ml/ha) } & Means \\
$\mathrm{GR}_{1}$ (Control) & $\mathrm{GR}_{2}(\mathbf{5 0})$ & $\mathrm{GR}_{3}(\mathbf{1 0 0})$ \\
$\mathrm{T}_{2}(60: 40)$ & $72.50 \mathrm{fg}$ & $86.63 \mathrm{bc}$ & $82.40 \mathrm{cde}$ & $80.51 \mathrm{~b}$ \\
$\mathrm{~T}_{3}(120: 80)$ & $79.37 \mathrm{de}$ & $88.13 \mathrm{abc}$ & $83.87 \mathrm{~cd}$ & $83.79 \mathrm{~b}$ \\
$\mathrm{~T}_{4}(180: 120)$ & $83.73 \mathrm{~cd}$ & $94.13 \mathrm{a}$ & $90.40 \mathrm{ab}$ & $89.42 \mathrm{a}$ \\
Means & $75.70 \mathrm{c}$ & $86.56 \mathrm{a}$ & $82.17 \mathrm{~b}$ &
\end{tabular}

Mean values of different letters in respective groups are significant at $(P<0.05) . L S D_{0.05} ; N P$ doses $=4.5127 ;$ NAA levels $=2.5515 ; N P$ doses*NAA levels $=5.1029$.

Table 2: Effect of $N: P$ and NAA application on number of tillers at maturity of wheat.

\begin{tabular}{lllll}
$\begin{array}{l}\text { NP Levels } \\
\text { (kg/ha) }\end{array}$ & \multicolumn{2}{l}{ NAA Levels (ml/ha) } & \multicolumn{2}{c}{ Means } \\
$\mathrm{GR}_{1}$ (Control) & $\mathrm{GR}_{2}(50)$ & $\mathrm{GR}_{3}(\mathbf{1 0 0 )}$ \\
$\mathrm{T}_{1}($ Control) & $141.00 \mathrm{j}$ & $157.67 \mathrm{hi}$ & $151.67 \mathrm{i}$ & $150.11 \mathrm{~d}$ \\
$\mathrm{~T}_{2}(60: 40)$ & $160.67 \mathrm{~h}$ & $171.67 \mathrm{fg}$ & $167.33 \mathrm{~g}$ & $166.56 \mathrm{c}$ \\
$\mathrm{T}_{3}(120: 80)$ & $178.00 \mathrm{ef}$ & $192.00 \mathrm{~d}$ & $184.00 \mathrm{e}$ & $184.67 \mathrm{~b}$ \\
$\mathrm{~T}_{4}(180: 120)$ & $203.67 \mathrm{c}$ & $226.33 \mathrm{a}$ & $215.67 \mathrm{~b}$ & $215.22 \mathrm{a}$ \\
Means & $170.83 \mathrm{c}$ & $186.92 \mathrm{a}$ & $179.67 \mathrm{~b}$ &
\end{tabular}

Mean values of different letters in respective groups are significant at $(P<0.05) . L S D_{0.05} ; N P$ Doses $=4.5318 ;$ NAA Levels $=3.2718 ; N P$ doses ${ }^{*} N A A$ levels $=6.5435$.

\section{Spike length (cm)}

Spike length is the most important contributor of grain yield which effects on number of grains 
spike $^{-1}$, spike weight and thousand grains weight. From the data given in Table 3 it is evident that there were significant differences in the spike length by different combination of $\mathrm{N}$ and $\mathrm{P}_{2} \mathrm{O}_{5}$ with application of naphthalene acetic acid on late sown wheat. Maximum length of spike $(11.87 \mathrm{~cm})$ was produced by $\mathrm{T}_{4}\left(180: 120 \mathrm{~kg} \mathrm{ha}^{-1} \mathrm{~N}\right.$ : P) followed by $\mathrm{T}_{3}(11.31 \mathrm{~cm})$ and application of NAA GR $@ 50$ $\mathrm{ml} \mathrm{ha}{ }^{-1}$ developed maximum spike length $(11.89 \mathrm{~cm})$ followed by $\mathrm{GR}_{3}(11.31 \mathrm{~cm})$. In interaction $\mathrm{T}_{4} \mathrm{xGR}$ $(12.33 \mathrm{~cm})$ registered maximum spike length. The treatments $T_{2}$ and $T_{3}$ are non-significant from each other.Minimum spike length was noted in $\mathrm{T}_{1}$ (control) $(10.31 \mathrm{~cm})$ and in $\mathrm{GR}_{1}(10.22 \mathrm{~cm})$. In interaction, $\mathrm{T}_{1} \mathrm{xGR}$ marked the shortest spike length $(8.98 \mathrm{~cm})$. Laghari et al. (2010) and Khan et al. (2014) depicted that fertilizer application with application of NAA significantly enhanced the growth of spikes by better nutrients uptake.

Table 3: Effect of N:P and NAA application on spike length $(\mathrm{cm})$ of wheat.

\begin{tabular}{lllll}
$\begin{array}{l}\text { NP Levels } \\
\text { (kg/ha) }\end{array}$ & \multicolumn{2}{l}{ NAA Levels (ml/ha) } & \multicolumn{2}{c}{ Means } \\
$\mathrm{GR}_{1}$ (Control) & $\mathrm{GR}_{2}(\mathbf{5 0})$ & $\mathrm{GR}_{3}(\mathbf{1 0 0})$ \\
$\mathrm{T}_{2}(60: 40)$ & $10.27 \mathrm{e}$ & $11.46 \mathrm{bc}$ & $11.23 \mathrm{~cd}$ & $10.99 \mathrm{~b}$ \\
$\mathrm{~T}_{3}(120: 80)$ & $10.42 \mathrm{e}$ & $11.98 \mathrm{abc}$ & $11.52 \mathrm{bc}$ & $11.31 \mathrm{~b}$ \\
$\mathrm{~T}_{4}(180: 120)$ & $11.23 \mathrm{~cd}$ & $12.33 \mathrm{a}$ & $12.06 \mathrm{ab}$ & $11.87 \mathrm{a}$ \\
Means & $10.22 \mathrm{c}$ & $11.89 \mathrm{a}$ & $11.31 \mathrm{~b}$ &
\end{tabular}

Mean values of different letters in respective groups are significant at $(P<0.05) . L S D_{0.05} ; N P$ Doses $=0.4892 ;$ NAA Levels $=0.3896 ; N P$ doses $^{*} N$ AA levels $=0.7791$.

\section{Spike weight (gm)}

The spike is essential part of the wheat plant because it is the portion that brings the "new life stuff" wheat grains and contributes to the grain yield. The data presented in Table 4 showed significant differences in the weight of the spikes by application of $\mathrm{N}$ and $\mathrm{P}$ with NAA at different combination in late sown wheat. Maximum spike weight $(3,08 \mathrm{~g})$ was depicted by $\mathrm{T}_{4}$ (180:120 kg ha-1 N:P) followed by $\mathrm{T}_{3}(2.58 \mathrm{~g})$ while NAA application @ $50 \mathrm{ml} \mathrm{ha}^{-1}$ presented maximum spike weight $(2.89 \mathrm{~g})$ followed by $\mathrm{GR}_{3}(2.63 \mathrm{~g})$. In interaction, maximum spike weight was recorded by $\mathrm{T}_{4} \mathrm{xGR}_{2}$ (3.35 gm). However, statistically there is no difference between $T_{2}$ and $T_{3}$. Mean values of minimum spike weight measured by control treatment $\mathrm{T}_{1}(2.37 \mathrm{~g})$ and $\mathrm{GR}_{1}(2.42 \mathrm{~g})$ and in interaction $\mathrm{T}_{1} \mathrm{xGR}_{1}$ recorded minimum spike weight $(2.13 \mathrm{~g})$. Spike weight is controlled by environment, genotype, soil fertility and time of sowing and flowering. In case of late sowing, exogenous application of plant growth regulator (NAA) have positive effect in this manner as described by Bakhsh et al. (2011) and Mona et al. (2013). This treatment $\left(\mathrm{T}_{4} \mathrm{xGR} \mathrm{CR}_{2}\right)$ also produced longer spikes with more number of grains spike ${ }^{-1}$ which contributed heavier spikes.

Table 4: Effect of N:P and NAA application on spike weight $(\mathrm{gm})$ of wheat.

\begin{tabular}{lllll}
$\begin{array}{l}\text { NP Levels } \\
\text { (kg/ha) }\end{array}$ & \multicolumn{2}{l}{ NAA Levels (ml/ha) } & \multicolumn{2}{c}{ Means } \\
$\mathrm{TR}_{1}($ Control $)$ & $2.13 \mathrm{~h}$ & $2.60 \mathrm{cde}$ & $2.37 \mathrm{fg}$ & $2.37 \mathrm{c}$ \\
$\mathrm{T}_{2}(60: 40)$ & $2.38 \mathrm{efg}$ & $2.78 \mathrm{bcd}$ & $2.55 \mathrm{~d}-\mathrm{g}$ & $2.57 \mathrm{~b}$ \\
$\mathrm{~T}_{3}(120: 80)$ & $2.30 \mathrm{gh}$ & $2.84 \mathrm{bc}$ & $2.60 \mathrm{def}$ & $2.58 \mathrm{~b}$ \\
$\mathrm{~T}_{4}(180: 120)$ & $2.89 \mathrm{~b}$ & $3.35 \mathrm{a}$ & $3.01 \mathrm{~b}$ & $3.08 \mathrm{a}$ \\
Means & $2.42 \mathrm{c}$ & $2.89 \mathrm{a}$ & $2.63 \mathrm{~b}$ &
\end{tabular}

Mean values of different letters in respective groups are significant at $(P<0.05) . L S D_{0.05} ; N P$ Doses $=0.2642 ;$ NAA Levels $=0.1453 ; \mathrm{NP}$ doses ${ }^{*} N A$ A levels $=0.2361$.

\section{0 grains weight $(g)$}

Thousand grains weight is directly associated with grain yield and therefore requires due consideration. The effect of NP levels with NAA doses shows significant on 1000-grain weight (Table 5). The maximum 1000-grains weight (46.95 g) was found @ 180:120 N:P kg ha-1 in $\mathrm{T}_{4}$ followed by $\mathrm{T}_{3}(42.09 \mathrm{~g})$, while at the rate $50 \mathrm{ml} \mathrm{ha}^{-1} \mathrm{NAA}$ application recorded maximum 1000-grain weight (43.01 g) followed by $\mathrm{GR}_{2}(39.48 \mathrm{~g})$. While $\mathrm{T}_{4} \mathrm{xGR}$ recorded maximum 1000 grain weight $(51.04 \mathrm{gm})$ in interaction but values of interaction having non-significant differences. Minimum thousand grain weight recorded by control fertilizer treatment $\mathrm{T}_{1}(31.54 \mathrm{~g})$ and control NAA treatment $\mathrm{GR}_{1}(36.26 \mathrm{~g})$. In interaction $\mathrm{T}_{1} \mathrm{xGR}_{1}$ recorded minimum 1000 grains weight $(29.30 \mathrm{~g})$. This could be attributed to exogenous NAA use and N,P fertilizer uptake which enables the wheat to store more assimilates per metabolites in the grain, that results in heavier grains with more grain weight. Our results are in confirmation of the studies carried out by Islam and Jahan (2016) and Akhtar (2017).

\section{Number of grains spike-1}

The potential of grains spike ${ }^{-1}$ is registered in terms of its number, so very close association between grain yield and grains spike ${ }^{-1}$ occurred. Several factors affect grains per spike, such as cultivar, wheat clan (winter versus spring), soil fertility, climatic conditions and management practices. The data described in Table 6 
manifested that the grains spike ${ }^{-1}$ differed significantly by combine application of nitrogen and phosphorus with NAA in late sown wheat. The maximum number of grains spike ${ }^{-1}$ depicted in fertilizers doses (56.67) @ 180:120 N:P kg ha-1 by $\mathrm{T}_{4}$ followed by $\mathrm{T}_{3}$ (53.44) and in NAA application marked (54.08) @ $50 \mathrm{ml} \mathrm{ha} \mathrm{ha}^{-1}\left(\mathrm{GR}_{2}\right)$ followed by $\mathrm{GR}_{3}$ (51.33). $\mathrm{T}_{4} \mathrm{xGR}$ (62.00) marked maximum number of grains per spike in interaction. The lowest number of grains spike ${ }^{-1}$ expressed by $\mathrm{T}_{1}(44.11)$ and $\mathrm{GR}_{1}(47.58)$ and $\mathrm{T}_{1} \mathrm{xGR}$ (42.33) in interaction. Here, the rate of promotion of number of grains per spike increased by foliar application of $50 \mathrm{ml} \mathrm{NAA} \mathrm{ha-1} \mathrm{GR}_{2}$ and $\mathrm{T}_{4}(180 \mathrm{~N}$ and $120 \mathrm{P}_{2} \mathrm{O}_{5} \mathrm{~kg} \mathrm{ha}^{-1}$ ) over control but $\mathrm{GR}_{3}$ interacted $\left(100 \mathrm{ml} \mathrm{ha}^{-1}\right)$ with $\mathrm{T}_{4}$ reduced the grains per spike. It is worthy to note that interaction of $50 \mathrm{ml} \mathrm{ha}^{-1}$ with NP levels significantly increase this character.

Table 5: Effect of N: P and NAA application on 1000 grains weight $(\mathrm{gm})$ of wheat.

\begin{tabular}{lllll}
$\begin{array}{l}\text { NP Levels } \\
\text { (kg/ha) }\end{array}$ & \multicolumn{2}{l}{ NAA Levels (ml/ha) } & \multicolumn{2}{l}{ Means } \\
$\mathrm{GR}_{1}$ (Control) & $\mathrm{GR}_{2}(\mathbf{5 0 )}$ & $\mathrm{GR}_{3}(\mathbf{1 0 0 )}$ & \\
$\mathrm{T}_{1}$ (Control) & 29.30 & 34.58 & 30.73 & $31.54 \mathrm{~d}$ \\
$\mathrm{~T}_{2}(60: 40)$ & 34.20 & 41.60 & 37.48 & $37.76 \mathrm{c}$ \\
$\mathrm{T}_{3}(120: 80)$ & 38.48 & 44.81 & 42.98 & $42.09 \mathrm{~b}$ \\
$\mathrm{~T}_{4}(180: 120)$ & 43.08 & 51.04 & 46.73 & $46.95 \mathrm{a}$ \\
Means & $36.26 \mathrm{c}$ & $43.01 \mathrm{a}$ & $39.48 \mathrm{~b}$ &
\end{tabular}

Mean values of different letters in respective groups are significant at $(P<0.05) . L S D_{0.5} ; N P$ Doses $=3.3348 ;$ NAA Levels $=0.6856 ; N P$ doses ${ }^{*} N A$ A levels $=1.3913$.

Table 6: Effect of N: P and NAA application on number of grains spike $e^{-1}$ of wheat.

\begin{tabular}{lllll}
$\begin{array}{l}\text { NP Levels } \\
\text { (kg/ha) }\end{array}$ & \multicolumn{2}{l}{ NAA Levels (ml/ha) } & Means \\
$\mathrm{GR}_{1}$ (Control) & $\mathrm{GR}_{2}(\mathbf{5 0})$ & $\mathrm{GR}_{3}(\mathbf{1 0 0})$ & \\
$\mathrm{T}_{1}($ Control) & $42.33 \mathrm{~h}$ & $46.33 \mathrm{~g}$ & $43.67 \mathrm{~h}$ & $44.11 \mathrm{~d}$ \\
$\mathrm{~T}_{2}(60: 40)$ & $48.00 \mathrm{fg}$ & $51.00 \mathrm{~d}$ & $50.33 \mathrm{de}$ & $49.78 \mathrm{c}$ \\
$\mathrm{T}_{3}(120: 80)$ & $49.00 \mathrm{ef}$ & $57.00 \mathrm{~b}$ & $54.33 \mathrm{c}$ & $53.44 \mathrm{~b}$ \\
$\mathrm{~T}_{4}(180: 120)$ & $51.00 \mathrm{~d}$ & $62.00 \mathrm{a}$ & $57.00 \mathrm{~b}$ & $56.67 \mathrm{a}$ \\
Means & $47.58 \mathrm{c}$ & $54.08 \mathrm{a}$ & $51.33 \mathrm{~b}$ &
\end{tabular}

Mean values of different letters in respective groups are significant at $(P<0.05) . L S D_{0.05} ; N P$ Doses $=1.26 ;$ NAA Levels $=0.86 ; \mathrm{NP}$ doses ${ }^{*} N A$ A levels $=1.7309$.

\section{Grain yield (kg ha-1)}

Many attributes like tillering plant ${ }^{-1}$, number of grains per spike, 1000 grains weight etc., contribute to grain yield. Table 7 shows the result of grain yield of wheat as affected by nitrogen and phosphorus levels and foliar application of NAA. Maximum grain yield was attained by $\mathrm{T}_{4}\left(4381.37 \mathrm{~kg} \mathrm{ha}^{-1}\right)$ by use of $180 \mathrm{~N}$ and $120 \mathrm{P} \mathrm{kg} \mathrm{ha}^{-1}$ followed by $\mathrm{T}_{3}(3800.03 \mathrm{~kg}$ $\left.\mathrm{ha}^{-1}\right)$. The application of NAA @ $50 \mathrm{ml} \mathrm{ha}^{-1}$ recorded significantly maximum grain yield $\left(4102.70 \mathrm{~kg} \mathrm{ha}^{-1}\right)$ followed by (100 $\left.\mathrm{ml} \mathrm{ha}^{-1} \mathrm{NAA}\right)$ from $\mathrm{GR}_{3}(3693.17$ $\left.\mathrm{kg} \mathrm{ha}{ }^{-1}\right)$. Interaction of NAA levels and N P doses remained non-significant but visual differences can be found in the data. Minimum grain yield was attained in control where no application of fertilizers and NAA was carried out. The data also shows application of NAA increased the efficiency of fertilizers by converting biomass (photosynthates) into grain yield. However optimum dose of $50 \mathrm{ml} \mathrm{ha}^{-1}$ recorded best values than other NAA levels and fertilizers N: P $\left(180: 120 \mathrm{~kg} \mathrm{ha}^{-1}\right)$ levels. Similar results were found by Akhtar (2017). Our treatment (T4) and foliar spray of NAA @ $50 \mathrm{ml} \mathrm{ha}^{-1}$ recorded best results in these traits. NAA also promotes more photosynthates towards spikes and grains which ultimately resulted in maximum grain yield in late sown wheat. The results of Islam and Jahan (2016) also witnessed the same situation. They reported use of NAA with $\mathrm{N}$ fertilizer increased their grain yield also.

Table 7: Effect of N:P and NAA application on grain yield $\left(\mathrm{kg} \mathrm{ha}^{-1}\right)$ of wheat.

\begin{tabular}{lllll}
$\begin{array}{l}\text { NP Levels } \\
\text { (kg/ha) }\end{array}$ & \multicolumn{2}{l}{ NAA Levels (ml/ha) } & Means \\
$\mathrm{GR}_{1}$ (Control) & $\mathrm{GR}_{2}(\mathbf{5 0})$ & $\mathrm{GR}_{3}(\mathbf{1 0 0})$ & \\
$\mathrm{T}_{2}(60: 40)$ & 3227.00 & 3859.84 & 3514.62 & $3533.82 \mathrm{c}$ \\
$\mathrm{T}_{3}(120: 80)$ & 3525.13 & 4166.53 & 3708.44 & $3800.03 \mathrm{~b}$ \\
$\mathrm{~T}_{4}(180: 120)$ & 4069.62 & 4758.89 & 4315.59 & $4381.37 \mathrm{a}$ \\
Means & $3247.53 \mathrm{c}$ & $4102.70 \mathrm{a}$ & $3693.17 \mathrm{~b}$ &
\end{tabular}

Mean values of different letters in respective groups are significant at $(P<0.05) . L S D_{0.5} ; N P$ Doses $=176.12 ;$ NAA Levels $=65.378 ; \mathrm{NP}$ doses $*$ NA levels $=130.76$

\section{Biological yield $\left(\mathrm{kg} \mathrm{ha}^{-1}\right)$}

Biological yield depends on plant height and number of tillers per unit area. Physiologically it is trait of vegetative growth. The data provided in Table 8 revealed biological yield by application of $\mathrm{N}: \mathrm{P}$ with NAA in late cultivated wheat. The maximum biological yield was acquired by $\mathrm{T}_{4}\left(9826.82 \mathrm{~kg} \mathrm{ha}^{-1}\right)$ followed by $\mathrm{T}_{3}\left(8314.86 \mathrm{~kg} \mathrm{ha}^{-1}\right)$ while by foliar spray of NAA @ $50 \mathrm{ml} \mathrm{ha}^{-1}$ recorded maximum biological yield $\left(8845.72 \mathrm{~kg} \mathrm{ha}^{-1}\right)$ followed by $\mathrm{GR}_{3}(8316.03 \mathrm{~kg}$ $\left.\mathrm{ha}^{-1}\right)$. Interaction among fertilizers doses and NAA levels were also significant as shown in the Table such as $\mathrm{T}_{4} \mathrm{xGR}_{2}\left(10486.19 \mathrm{~kg} \mathrm{ha} \mathrm{g}^{-1}\right)$. While minimum biological yield was observed from control where no 
application of fertilizers in $\mathrm{T}_{1}\left(626119 \mathrm{~kg} \mathrm{ha}^{-1}\right)$ and NAA in GR $_{1}\left(6860.27 \mathrm{~kg} \mathrm{ha}{ }^{-1}\right)$. Their interaction recorded minimum biological yield $\mathrm{T}_{1} \mathrm{xGR}_{1}$ (4054.46 $\mathrm{kg} \mathrm{ha}^{-1}$ ). Khan et al. (2009) also showed maximum results by applying @ 180:135 N:P kg ha-1. They unveiled that the improved growth of the vegetative period with improving $\mathrm{N}$ levels can be accredited to the nitrogen's most important functions, towards promoting vegetative growth. Phosphorus appears to have an additive impact on crop growth supplied, it is provided in a balanced proportion to that of the nitrogen applied for root development, stem thickness, conversion of vegetative growth into reproductive stage and also give grain vigor.

Table 8: Effect of N:P and NAA application on biological yield $(\mathrm{kg} / \mathrm{h})$ of wheat.

\begin{tabular}{lllll}
$\begin{array}{l}\text { NP Levels } \\
\text { (kg/ha) }\end{array}$ & \multicolumn{2}{l}{ NAA Levels (ml/ha) } & \multicolumn{2}{l}{ Means } \\
$\mathrm{GR}_{1}$ (Control) & $\mathrm{GR}_{2}(\mathbf{5 0 )}$ & $\mathrm{GR}_{3}(\mathbf{1 0 0 )}$ & \\
$\mathrm{T}_{1}($ Control) & $4054.46 \mathrm{~h}$ & $7652.82 \mathrm{e}$ & $7076.30 \mathrm{fg}$ & $6261.19 \mathrm{~d}$ \\
$\mathrm{~T}_{2}(60: 40)$ & $6806.88 \mathrm{~g}$ & $8238.56 \mathrm{~d}$ & $7833.95 \mathrm{de}$ & $7626.47 \mathrm{c}$ \\
$\mathrm{T}_{3}(120: 80)$ & $7582.02 \mathrm{ef}$ & $9005.28 \mathrm{c}$ & $8357.27 \mathrm{~d}$ & $8314.86 \mathrm{~b}$ \\
$\mathrm{~T}_{4}(180: 120)$ & $8997.69 \mathrm{c}$ & $10486.19 \mathrm{a}$ & $9996.58 \mathrm{~b}$ & $9826.82 \mathrm{a}$ \\
Means & $6860.27 \mathrm{c}$ & $8845.72 \mathrm{a}$ & $8316.03 \mathrm{~b}$ &
\end{tabular}

Mean values of different letters in respective groups are significant at $(P<0.05) . L S D_{0.05} ; N P$ Doses $=459.55 ;$ NAA Levels $=167.28 ; \mathrm{NP}$ doses $*$ NAA levels $=334.56$

\section{Straw yield $\left(\mathrm{kg} \mathrm{ha} \mathrm{a}^{-1}\right)$}

Straw yield data presented by application of nitrogen and phosphorus with naphthalene acetic acid in late sown wheat in Table 9. Maximum straw yield ( 5445.45 $\left.\mathrm{kg} \mathrm{ha} \mathrm{h}^{-1}\right)$ was registered by $\mathrm{T}_{4}\left(180: 120 \mathrm{~N}: \mathrm{P} \mathrm{kg} \mathrm{ha}{ }^{-1}\right)$ followed by $\left(120: 80 \mathrm{~N}: \mathrm{P} \mathrm{kg} \mathrm{ha}^{-1}\right)$ in $\mathrm{T}_{3}(4514.83 \mathrm{~kg}$ $\left.\mathrm{ha}^{-1}\right)$ and $\left(4743.01 \mathrm{~kg} \mathrm{ha}^{-1}\right)$ was obtained in $\mathrm{GR}_{2}(50$ $\left.\mathrm{ml} \mathrm{ha}^{-1}\right)$ followed by $\left(4622.86 \mathrm{~kg} \mathrm{ha}^{-1}\right)$ in $\mathrm{GR}_{3}(100 \mathrm{ml}$ NAA ha-1). Whereas their interaction such as $\mathrm{T}_{4} \times \mathrm{GR}_{2}$ shows maximum straw yield $\left(5727.30 \mathrm{~kg} \mathrm{ha}^{-1}\right)$. The minimum straw yield depicted by control treatment in which $\mathrm{T}_{1}$ recorded $3251.88 \mathrm{~kg} \mathrm{ha}^{-1}$ and $\mathrm{GR}_{1}(3612.73$ $\left.\mathrm{kg} \mathrm{ha}^{-1}\right)$ while their interaction showed $(1886.09 \mathrm{~kg}$ $\left.\mathrm{ha}^{-1}\right)$ in $\mathrm{T}_{1} \times \mathrm{RR}_{1}$. The increase in straw yield might have been due to adequate supply of fertilizers and more number of tillers, which emerged and produced by taller plants. Closely related findings found by Akhtar et al. (2017). They unveiled that increase in grain and straw yields may be due to sufficient crop quantities and a reasonable proportion of plant nutrients supplied to the crop as per need during the critical growth period resulting in favorable increase in yield attributing characters which ultimately led towards an increase in economic yield.

Table 9: Effect of N:P and NAA application on straw yield $\left(\mathrm{kg} \mathrm{ha}^{-1}\right)$ of wheat.

\begin{tabular}{lllll}
$\begin{array}{l}\text { NP Levels } \\
\text { (kg/ha) }\end{array}$ & \multicolumn{2}{l}{ NAA Levels (ml/ha) } & \multicolumn{2}{c}{ Means } \\
& $\begin{array}{l}\text { GR }_{1}(\text { Con- } \\
\text { trol) }\end{array}$ & GR $_{2}(\mathbf{5 0})$ & GR $_{3}(\mathbf{1 0 0})$ & \\
& & & & \\
$\mathrm{T}_{1}($ Control $)$ & $1886.09 \mathrm{~h}$ & $4027.27 \mathrm{ef}$ & $3842.29 \mathrm{fg}$ & $3251.88 \mathrm{~d}$ \\
$\mathrm{~T}_{2}(60: 40)$ & $3579.88 \mathrm{~g}$ & $4378.72 \mathrm{~cd}$ & $4319.34 \mathrm{de}$ & $4092.65 \mathrm{c}$ \\
$\mathrm{T}_{3}(120: 80)$ & $4056.89 \mathrm{def}$ & $4838.76 \mathrm{~b}$ & $4648.83 \mathrm{bc}$ & $4514.83 \mathrm{~b}$ \\
$\mathrm{~T}_{4}(180: 120)$ & $4928.07 \mathrm{~b}$ & $5727.30 \mathrm{a}$ & $5680.99 \mathrm{a}$ & $5445.45 \mathrm{a}$ \\
Means & $3612.73 \mathrm{c}$ & $4743.01 \mathrm{a}$ & $4622.86 \mathrm{~b}$ &
\end{tabular}

Mean values of different letters in respective groups are significant at $(P<0.05) . L S D_{0.5 ;}$ NP Doses $=283.45 ;$ NAA Levels $=102.12 ; \mathrm{NP}$ doses* $N A$ A levels $=204.25$

\section{Productivity score}

Productivity score means the rate per unit area or per unit volume at which economic yield (grain + biological yield) produced. Productivity score also based on quality aspects like harvest index. The contribution of nitrogen and phosphorus fertilizers have prominence in measurement of productivity score of wheat. It is a tool in which dry matter or biological yield with grain yield taken as standard economic yield. The treatment having best productivity score considered superior in economic value and more profitable. The data provided in Table 10 manifested that productivity score differed significantly by application nitrogen and phosphorus with NAA in late sown wheat. The highest productivity score recorded (14252.79) in $\mathrm{T}_{4}$ (180:120 N:P kg ha $\left.{ }^{-1}\right)$ followed by $\mathrm{T}_{3}(12160.61)$ and (12994.90) obtained in $\mathrm{GR}_{2} @ 50 \mathrm{ml} \mathrm{ha} \mathrm{m}^{-1}$ followed by (12053.74) in $\mathrm{GR}_{3}$. While in interaction of these two factors $T_{4}\left(180: 120 \mathrm{~kg} \mathrm{ha}^{-1}\right) \times \mathrm{GR}_{2}\left(50 \mathrm{ml} \mathrm{ha}^{-}\right.$ $\left.{ }^{1}\right)$ marked maximum productivity score (15290.47). Though minimum productivity score was reckoned in control where there was no fertilizer and NAA used.

\section{Harvest index}

The relation between biological yield and grain yield was determined in terms of harvest index, which essentially expressed a crop's capacity to turn the accumulation of dry matter into grain yield. The data presented in Table 11 showed harvest index by application of $\mathrm{N}: \mathrm{P}$ with NAA in late sown wheat. The highest harvest index $48.89 \%$ was obtained in $\mathrm{T}_{1}$ (Control) followed by $\mathrm{T}_{2}$ (46.38) while (48.16\%) was recorded in $\mathrm{GR}_{1}$ (Control) followed by $\mathrm{GR}_{2}$ (46.48). In interaction $\mathrm{T}_{1}$ (control) $\mathrm{x} \mathrm{GR}_{2}$ (control) showed maximum harvest index (53.51\%). While 
minimum harvest index expressed by $\mathrm{T}_{4}(44.60)$ and $\mathrm{GR}_{3}(44.54)$ and their interaction $\mathrm{T}_{4} \mathrm{xGR}_{3}$ also recorded (43.17) minimum harvest index. Similar type of results obtained from Hussain et al. (2018). They concluded that it is not necessary the treatment having best grain yield having high harvest index.

Table 10: Effect of N:P and NAA application on productivity score of wheat.

\begin{tabular}{|c|c|c|c|c|}
\hline \multirow{2}{*}{$\begin{array}{l}\text { NP Levels } \\
\text { (kg/ha) }\end{array}$} & \multicolumn{3}{|c|}{ NAA Levels (ml/ha) } & \multirow[t]{2}{*}{ Means } \\
\hline & $\begin{array}{l}\mathrm{GR}_{1} \\
\text { (Control) }\end{array}$ & $\mathrm{GR}_{2}(50)$ & $\mathrm{GR}_{3}(100)$ & \\
\hline $\mathrm{T}_{1}$ (Control) & $6276.35 \mathrm{~h}$ & $11325.78 \mathrm{f}$ & $10356.05 \mathrm{~g}$ & $9319.39 \mathrm{~d}$ \\
\hline $\mathrm{T}_{2}(60: 40)$ & $10081.31 \mathrm{~g}$ & $12145.26 \mathrm{~d}$ & $11393.45 \mathrm{ef}$ & $11206.67 \mathrm{c}$ \\
\hline $\mathrm{T}_{3}(120: 80)$ & $11153.64 \mathrm{f}$ & $13218.09 c$ & $12110.10 \mathrm{de}$ & $12160.61 \mathrm{~b}$ \\
\hline $\mathrm{T}_{4}(180: 120)$ & $13112.54 \mathrm{c}$ & $15290.47 \mathrm{a}$ & $14355.35 \mathrm{~b}$ & $14252.79 \mathrm{a}$ \\
\hline Means & $10155.96 \mathrm{c}$ & $12994.90 \mathrm{a}$ & $12053.74 \mathrm{~b}$ & \\
\hline
\end{tabular}

Table 11: Effect of N: P and NAA application on harvest index of wheat.

\begin{tabular}{lllll}
$\begin{array}{l}\text { NP Levels } \\
\text { (kg/ha) }\end{array}$ & NAA Levels (ml/ha) & \multicolumn{2}{c}{ Means } \\
$\mathrm{GR}_{1}$ (Control) & $53.51 \mathrm{a}$ & $47.41 \mathrm{bc}$ & $45.74 \mathrm{ef}$ & $48.89 \mathrm{a}$ \\
$\mathrm{T}_{2}(60: 40)$ & $47.42 \mathrm{~b}$ & $46.85 \mathrm{~cd}$ & $44.87 \mathrm{gh}$ & $46.38 \mathrm{~b}$ \\
$\mathrm{~T}_{3}(120: 80)$ & $46.50 \mathrm{~d}$ & $46.27 \mathrm{de}$ & $44.38 \mathrm{~h}$ & $45.71 \mathrm{c}$ \\
$\mathrm{T}_{4}(180: 120)$ & $45.23 \mathrm{fg}$ & $45.38 \mathrm{fg}$ & $43.17 \mathrm{i}$ & $44.60 \mathrm{~d}$ \\
Means & $48.16 \mathrm{a}$ & $46.48 \mathrm{~b}$ & $44.54 \mathrm{c}$ &
\end{tabular}

Mean values of different letters in respective groups are significant at $(P<0.05) . L S D_{0.05} ; N P$ Doses $=0.6623 ; N A A$ Levels $=0.1640 ; N P$ doses* $N A$ A levels $=0.0229$.

\section{Conclusions and Recommendations}

In this study, the use of fertilizers and growth regulators impacted the wheat yield and yield components significantly. Use of PGR (NAA) promised to enhance the grain yield. $50 \mathrm{ml} \mathrm{ha}^{-1}$ use of naphthalene acetic acid with use of $180 \mathrm{~kg} \mathrm{~N}$ and 120 $\mathrm{kg} \mathrm{P}_{2} \mathrm{O}_{5} \mathrm{ha}^{-1}$ is the best combination to enhance grain yield in late sown wheat.

\section{Novelty Statement}

Pakistan lying in that geographic area which is pound to climate change scenario and this climate change causes reduction in vegetative \& economical yield of our summer crops. Considering the importance of naphthalene acetic acid (PGR) in reclaiming the climate change in physiology of sorghum the present research is designed accordingly.

\section{Author's Contribution}

Iqtidat Hussain: Conceived the idea and overall management of the article.

Ejaz Ahmed Khan: Data entry in SPSS, Analyzed and technical input at every step.

Muhammad Afnan Rabbi: Did SPSS analysis and overall management of the article.

Muhammad Saad: Collected data.

Aitezaz Ali Asad Shahani: Collected references.

Conflict of interest

The authors have declared no conflict of interest.

\section{References}

Akhtar, N., 2017. Yield maximization through nutrient management in irrigated wheat (Triticum aestivum L.). (Doctoral Dissertation, JAU, JUNAGADH). pp. 2374

Aslam, M., E. Ahmad, A.G. Saguu, K. Hussain, M. Ayaz, U. Inayat, A. Hussain and Himayatullah. 2010. Effect of plant growth regular (NAA) and available soil moisture depletions on yield and yield components of chickpea. Sarhad J. Agric., 26(4): 325-335.

Bakhsh, I., H.U. Khan, M.Q. Khan and S. Javaria. 2011. Effect of naphthalene acetic acid and phosphorus levels on the yield potential of transplanted coarse rice. Sarhad J. Agric., 27(2): 161-165.

Gerami, F., A. Aynehband and E. Taherifard. 2013. The influence of legume and non-legume green manures along with nitrogen fertilizer levels on some traits of wheat (Triticum aestivum $\mathrm{L}$.) as Subsequent Crop. Ann. Res. Rev. Biol., pp. 314-322.

Hussain, I., E.A. Khan, U.K. Sadozai and I. Baksh. 2018. Metric traits studies in wheat varieties as affected by sowing techniques. Pak. J. Bot., 50(4): 1373-1378.

Islam, S. and N. Jahan. 2016. Effects of NAA and different nitrogen levels on nutrient uptake by Bari GOM-26 (Triticum aestivum L.). J. A. Soc. Bang. Sci., 42(1): 69-76. https://doi. org/10.3329/jasbs.v42i1.31751

Khan, P., M. Imtiaz, M. Aslam, S.K. Hussain, 
Nizamuddin, M.Y. Memon and S.U.H. Siddiqui. 2008. Effect of different nitrogen and phosphorus ratios on the performance of wheat cultivar Khirman. Sarhad J. Agri., 24(2): 233239.

Khan, P., M. Imtiaz, M.Y. Memon and M. Aslam. 2009. Response of wheat genotype 'MSH14'to different levels/ratios of nitrogen and phosphorus. Sarhad J. Agric., 25(1): 59-64.

Khan, P., M. Imtiaz, M.Y. Memon, M. Aslam, N. Depar, J.A. Shah and N. Ali. 2014. Response of wheat genotype NIA-Sundar to varying levels of nitrogen and phosphorus. Sarhad J. Agric., 30(3): 325-331.

Laghari, G.M., F.C. Oad, S. D Tunio, A.W. Gandahi, M.H. Siddiqui, A.W. Jagirani and S.M. Oad. 2010. Growth yield and nutrient uptake of various wheat cultivars under different fertilizer regimes. Sarhad J. Agric., 26(4): 489-
497.

Mona, E. Eleiwa, Maymona, A. Kord and S.A. Ibrahim. 2013. Response of barley plants to foliar application of growth regulators mixture of indole acetic acid, naphthalene acetic acid and zinc. Afr. J. Biotech., 12(23): 3653-3661

Murphy, K.M., P.G. Reeves and SS. Jones. 2008. Relationship between yield and mineral nutrient concentrations in historical and modern spring wheat cultivars. Euphytica, 163: 381- 390. https://doi.org/10.1007/s10681-008-9681-x

Raoofi, M.M., S. Dehghan, M. Keighobadi and O. Poodineh. 2014. Effect of naphthalene acetic acid in agriculture and the role of increase yield. Int. J. Agric. Crop. Sci., 7(14): 1378-1380.

Stoskopf, N.C., 1981. Cereals in understanding crop production by Reston Company, USA. pp. 137-139. 